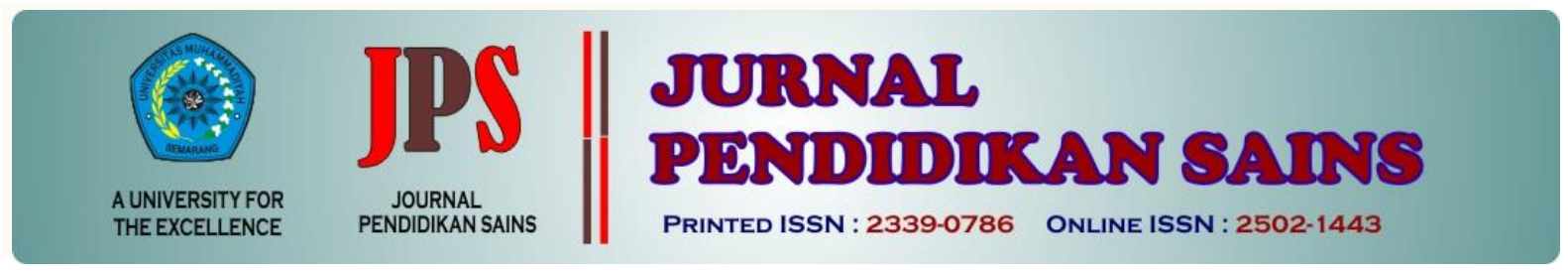

http://jurnal.unimus.ac.id/index.php/JPKIMIA

\title{
REFLEKSI PRAKTIKUM KIMIA ORGANIK CALON PENDIDIK KIMIA MENGGUNAKAN REKAMAN VIDEO
}

\author{
Oleh: \\ Eko Yuliyanto $^{1 *}$, Fitria Fatichatul Hidayah ${ }^{2}$, Enade Perdana Istyastono ${ }^{3}$, and Yosef Wijoyo ${ }^{4}$ \\ ${ }_{1,2}$ Muhammadiyah Semarang University, Semarang, Indonesia \\ ${ }^{3,4,5}$ Sanata Dharma University, Yogyakarta, Indonesia \\ *Corresponding author email: ekoyuliyanto@unimus.ac.id

$$
\frac{3 \text { ep.istyastono@gmail.com }}{4 \text { yosefw@usd.ac.id }}
$$$$
\text { ititriafatichatul@unimus.ac.id }
$$

\begin{tabular}{ll}
\hline \multicolumn{2}{l}{ Article history } \\
\hline Submission & $: 2018-10-15$ \\
Revised & $: 2018-11-15$ \\
Accepted & $: 2018-11-16$
\end{tabular}

Keyword:

Reflections, pre-service teacher of Chemistry Education, Organic, Video

\begin{abstract}
Organic chemistry is one of the courses that must be taken by a preservice teacher. However, not all students like the subject, on the other hand they have to learn. Practicum of Organic chemistry has been carried out for some time by chemistry education students. Therefore to bridge the gap and problems. It needs to be an improvement to find out the problem. Therefore it is necessary to reflect on organic chemistry practicum using videos. This research was in the form of observation of learning organic chemistry which was participated by 29 semester 3 chemistry education students with acetic acid synthesis material, saponification and synthesis of butyl acetate. Based on the results of the study concluded that 1). It is important to prepare students' skills in using equipment 2). Practical topics getting closer to everyday products, will be more interesting, 3).Preliminary confirmation before practicum is important to ensure student readiness, 4). Reflection is very helpful in reminding lecturers of the results of learning objectives.
\end{abstract}

\section{Pendahuluan}

Motivasi seseorang untuk menjadi guru beraneka ragam. Berdasarkan data penelitian ada 4 kategori motivasi seseorang ingin menjadi guru yaitu nilai-nilai intrinsik (misalnya, kemampuan intelektual, suka bekerja dengan anak-anak), nilai ekstrinsik (misalnya, waktu untuk keluarga, keamanan kerja), nilai-nilai altruistik (misalnya, berbuat baik untuk masyarakat, membentuk masa depan anak-anak dan remaja) dan lingkungan kerja (misalnya, otonomi, peluang untuk mengembangkan jaringanprofesional) (Whitaker \& Valtierra, 2018, p. 171). Semangat mengajar seorang guru tentunya sejalan dengan semangat belajarnya calon guru di perguruan tinggi (Schiefele, 2017), salah satunya dalam belajar kimia organik. Mata kuliah ini merupakan salah satu bekal mereka dalam

*Corresponding Author:

$\begin{array}{ll}\text { Nama } & \text { : eko yuliyanto } \\ \text { Lembaga } & : \text { Pendidikan Kimia, UNIMUS } \\ \text { Email } & \text { : ekoyuliyanto@ } \text { unimus.ac.id }\end{array}$ 
mengajar di kelas, oleh karena itu seorang calon guru tentunya juga harus bersemangat dalam mempelajari kimia organi, namun kenyataan di lapagan tidak seperti teori yang ada, oleh karena itu diperlukan fasilitas atau cara untuk dapat meningkatkan motivasi belajar calon pendidik kimia dalam menyiapkan kompetensinya untuk menjadi guru di masa depan. Pengalaman buruk saat di sekolah atau pada mata kuliah sebelumnya dimungkinkan dapat mempengaruhi motivasi calon guru dalam mengajar, oleh karena itu diperukan cara untuk meningkatkan motivasi calon guru untuk semangat dalam belajar(Mansfield \& Volet, 2010).

Salah satu cara untuk memperbaiki motivasi para calon guru yaitu memperbaiki pengelolan kelas (Schiefele, 2017), sehingga menambah kenyamanan belajar, yaitu cara mengajar dosen. Seorang dosen untuk dapat memberikan pembelajaran yang baik tentunya harus mengevaluasi proses pembelajaran sebelumnya, hal ini dilakukan dengan cara refleksi. Selain itu untuk mengetahui perkembangan peserta didik (calon guru) juga dilakukan dengan merefleksikan setiap pembelajaran yang dilakukan oleh dosen. Refleksi guru dapat mendukung perkembangan profesionalitas guru ataupun calon guru (Dervent, 2015, p. 260). Ada banyak cara dalam melakukan refleksi: jurnal reflksi, refleksi wawancara, konfrensi observasi teman sejawat, diskusi group, atau yang lebih canggih menggunakan video, blog, dan portofolio elektronik (Dervent, 2015, p. 261).

Refleksi mendorong para guru untuk menghadapi asumsi sebelumnya tentang mengajar dan belajar, mempertanyakan praktik pengajaran mereka sendiri, dan untuk menyelidiki bukan hanya apa yang berhasil di kelas tetapi juga mengapa itu berhasil (Firdyiwek \& Scida, 2014, p. 115). Refleksi adalah prosedur baik yang dapat digunakan para guru untuk menyelidiki, dan menjadikan praktik mengajar mereka lebih baik (Fatemipour, 2013). Harapannya dengan adanya refleksi akan ditemukan kelemahan dalam setiap pembelajaran supaya dapat segera dilakukan perbaikan. Adanya perbaikan yang berkelanjutan dapat memperbaiki proses pembelajaran dan meningkatkan kenyamanan peserta didik dalam pembelajaran. Oleh karena itu perlunya adanya penelitian penerapan refleksi pembelajaran guru untuk dapat meningkatkan motivasi belajar calon guru kimia di universitas, salah satunya dalam mempelajari kimia organik.

\section{Metode Penelitian}

Jenis Penelitian

Penelitian ini merupakan penelitian kualitatif. Penelitan melibatkan mahasiswa semester 3 yang sedang menempuh matakuliah kimia organik dengan materi asam karboksilat. Selama mahasiswa melakukan kegiatan raktikum kimia organik, proses pembelajaran direkam untuk digankan sebagai bahan observasi. Kegiatan praktikumnya meliputi praktikum sintesis asam asetat, reaksi asam karboksilat berupa penyabunan, dan sintesis butyl asesta.

\section{Waktu dan Tempat Penelitian}

Penelitian dilakukan di laboratorium kimia, Universitas Muhammadiyah Semarang. Penelitian dilakukan pada bulan Mei-Juni 2018.

\section{Target/Subjek Penelitian}

Pada penelitian ini melibatkan mahasiswa pendidikan kimia universitas muhammadiyah semarang semester 3 sebanyak 29 orang. Mahasiswa mengikuti pembelajaran praktikum kimia organik sebanyak 3 kali pertemuan dengan topic berbeda. Pembelajaran praktikum kimia organik ditempuh 1 SKS (3 jam pembelajaran).

\section{Prosedur}

Penelitian ini delakukan dengan beberapa langkah yaitu

1. Pengajar mempersiapkan perangkat pembelajaran dan bahan praktikum;

2. Dosen melakukan pembelajaran dan direkam berupa Video;

3. Dosen melakukan refleksi setiap kali pertemuan, begitu juga mahasiswanya;

4. Analisis refleksi menggunakan instrument yang dikembangkan oleh (Wijoyo, Rahayu, \& Dwiprahasto, 2016); 
5. Observasi kegiatan praktikum dengan menggunakan hasil rekaman Video pembelajaran;

6. Evaluasi hasil pembelajaran.

\section{Data, Intrumen, dan Teknik Pengumpulan Data}

Data penelitian ini meliputi: refleksi dosen, mahasiswa dan rekaman video pembelajaran. Instrumen refleksi merupakan instrument yang telah dikembangkan oleh Wijoyo, dkk. Konten refleksi meliputi konteks, pemberian pengalaman, refleksi oleh dosen dan mahasiswa dan tahap terakhir rencana aksi seteleh mengikuti pembelajaran. Penjabaran konten tersebut tercantum seperti pada table 1 .

Tabel 1. Tahapan refleksi dosen

\begin{tabular}{ll}
\hline \multicolumn{1}{c}{ Tahap } & \multicolumn{1}{c}{ Konten } \\
\hline Kontek & $\begin{array}{l}\text { Dosen menuliskan apa yang telah dilakukan untuk menggali prior } \\
\text { knowledge dari mahasiswa dan mengkaitkan relevansi materi } \\
\text { perkuliahan dengan kebutuhan mereka setelah lulus }\end{array}$ \\
\hline Pengalaman & $\begin{array}{l}\text { Dosen menuliskan apa yang telah Anda lakukan dalam } \\
\text { menyampaikan materi kepada mahasiswa; aktivitas apa yang } \\
\\
\text { dilakukan oleh mahasiswa sehingga mereka terlibat aktif dalam } \\
\text { pencarian dan konstruksi pengetahuan }\end{array}$ \\
\hline Refleksi & $\begin{array}{l}\text { Dosen menuliskan apa yang telah dilakukan dalam memandu } \\
\text { mahasiswa melakukan refleksi; dalam unsur apa saja proses refleksi }\end{array}$ \\
\hline tersebut dilakukan & $\begin{array}{l}\text { Dosen menuliskan apa yang telah dilakukan untuk membuat } \\
\text { mahasiswa lebih mendalami pengetahuan yang telah diperoleh }\end{array}$ \\
& selama perkuliahan dan dapat menerapkan pengetahuan tersebut di \\
& masyarakat
\end{tabular}

Sumber: (Wijoyo et al., 2016)

Dosen setelah melakukan pembelajaran melakukan refleksi sesuai ranah yang telah ditentukan, dan hasil refleksi dosen tertung pada table 2, table 3 dan tebel 4 .

Tabel 2. Refleksi pertemuan ke-1

\begin{tabular}{ll}
\hline \multicolumn{1}{c}{ Tahap } & \multicolumn{1}{c}{ Konten } \\
\hline Kontek & : Pertemuan ini dosen menghubungkan sintesis asam asetat dengan \\
& materi pada pertemuan ke-1 tentang asam karboksilat \\
\hline Pengalaman & : Mahasiswa diberi pengalamam melakukan praktikum sitesis asam \\
& asetat serta melakukan uji kualitatif. Pada saat praktikum ternyata \\
& mahasiswa masih belum mengenal beberapa senyawa yang baru \\
& dikenal, sehingga pada proses ini mahasiswa sedang mengkontruksi \\
& pengetahuan baru, begitu juga beberapa peralatan yang digunakan \\
& seperti refluks, hot plate, destilasi. Adanya hal-hal baru, sering \\
& diantara mereka saling bertanya, hal itu menunjukkan bahwa rasa \\
& ingin tahu mereka cukup tinggi. Namun, pada tahap uji kualitatif, \\
& masih banyak mahasiswa yang belum mampu menyajikan produk \\
& sintesis (blanko, uji fehling dan uji Potasium dicromate) untuk \\
& difoto. \\
\hline Refleksi & :Dosen meminta mahasiswa untuk mengisi dan mengumpulkan \\
& lembar refleksi pertemuan ke-2 pada hari berikutnya. \\
\hline Aksi & ada posen meminta mahasiswa untuk menyelesaikan pertanyaan yang \\
& reaksi kimia pada reaksi sintesis menggunakan software marvin. \\
\hline
\end{tabular}


Tabel 3. Refleksi pertemuan ke-2

\begin{tabular}{ll}
\multicolumn{1}{c}{ Tahap } & \multicolumn{1}{c}{ Konten } \\
\hline Kontek & : Pada pertemuan ini, dosen menanyakan mahasiswa tentang \\
& kegiatan apa yang akan dilakukan pada praktikum ke-2. Selain itu \\
& dosen juga melakukan kroscek kesipan mahasiswa dalam \\
& praktikum: bahan, volume bahan, prosedur, waktu dan perhitungan \\
& bahan yang digunakan dalam pembuatan sabun. \\
\hline Pengalaman & : Mahasiswa diberi pembelajaran praktikum membuat sabun, \\
& diawali dengan perhitungan perbandingan minyak, NaOH dan \\
& teknik pengadukan minyak menggunkan mixer. Selain itu mereka \\
& juga melakukan improvisasi dengan memberi pewarnaan dan \\
& penambahan aroma, namun gagal. Hal ini dikarenakan pewanginya \\
& tidak cocok dengan bahan yang digunakan. Selain itu mereka \\
& menjadi tahu kapan pengadukan dimulai dan dihentikan saat \\
& mengaduk pembuatan sabun. Bahkan setelah produknya jadi, \\
& mereka menyempatkan diri berfoto-foto dengan produk sabun yang \\
& sudah dibuat. Mereka termotivasi untuk membuat sabun \\
& dikemudian hari sebagai salah satu bagian wirausaha. \\
\hline Refleksi & Mahasiswa diminta melakukan refleksi pada pertemuan ke-2, dan \\
hal yang perlu dituliskan yaitu apa yang telah mereka alami dan \\
rasakan.
\end{tabular}

Tabel 4. Refleksi pertemuan ke-3

\begin{tabular}{ll}
\hline \multicolumn{1}{c}{ Tahap } & \multicolumn{1}{c}{ Konten } \\
\hline Kontek & Tahap ini dosen melakukan krosscek terhadap kesiapan \\
& mahasiswa dalam sintesis butyl asetat. Termasuk fungsi butyl asetat \\
& dalam kehidupan sehari-hari. Kroscek berupa Tanya jawab \\
& berkaitan: bahan, volume, perhitunga, aroma produk, hingga konsisi \\
& siswa siap untuk melakukan praktikum \\
\hline Pengalaman & : Pada tahap ini mahasiswa diberika breafing dan Tanya jawab \\
& kesiapan praktikum, selanjutnya siswa melakukan praktikum secara \\
& mandiri dan atas pengawasan dosen. Mahasiswa menyiapkan alat, \\
& bahan dan melakukan refluks secara mandiri, hal ini karena mereka \\
& telah melakukan refluk pada pertemuan sebelumnya, sehingga \\
& mereka semakin percaya diri dalam praktikum. Namun pada \\
& beberapa tahapan reaksi menggunakan corong pisah masih takut, \\
& karena reaksi menghasilkan gas. Oleh karena itu perlu arahan dan \\
& cotoh dari dosen dan asisten dosen. Selama proses pembelajaran \\
& mereka melakukan tebak-tebakan aroma produk sintesis butyl \\
& asetat. Akhirnya mereka menemukan aroma sesungguhnya dari \\
butyl asetat. & Mahasiswa diminta melakukan refleksi pada pertemuan ke-3, dan \\
hal yang perlu dituliskan yaitu apa yang telah mereka alami dan \\
rasakan. Pengumpulan lember refleksi dilakukan pada hari \\
berikutnya beserta laporan praktikum \\
\hline Dosen memberikan pekerjaan rumah: membuat laporan praktikum \\
(mekanisme reaksi menggunakan marvin). Adanya penerapan \\
software marvin membuat mereka terbiasa dalam pembelajaran \\
kimia organik dalam membuat mekanisme reaksi kimia pada \\
kegiatan praktikum.
\end{tabular}




\section{Refleksi Mahasisawa}

Penggabilan data refleksi menggunakan instrument yang telah dikembangkan (Wijoyo et al., 2016, p. 182). Pertanyaan refleksi mahasiswa meliputi beberap hal: Pada pertanyaan ke-1 mahasiswa diminta menguraikan dan menuliskan: tujuan pembelajaran, relevansi materi pembelajaran dengan profesi mahasiswa setelah lulus dan bagaimana proses pembelajaran pada pertanyaan ke-2 mahasiswa menuliskan pengetahuan-pengetahuan yang telah diperoleh setelah mempelajari materi, yang bermanfaat untuk mendukung profesi mahasiswa di masa mendatang. Pertanyaan 3, mahasiswa menuliskan nilai-nilai kehidupan apa saja yang telah diperoleh setelah mengikuti proses pembelajaran. Pertanyaan 4, mahasiswa menuliskan rencana aksi mahasiswa sebagai tindak lanjut terhadap pengetahuan dan nilainilai kehidupan, yang telah anda peroleh setelah mempelajari materi pembelajaran.

Berikut ini hasil rekap refleksi mahasiswa dapat disajikan sebagai berikut.

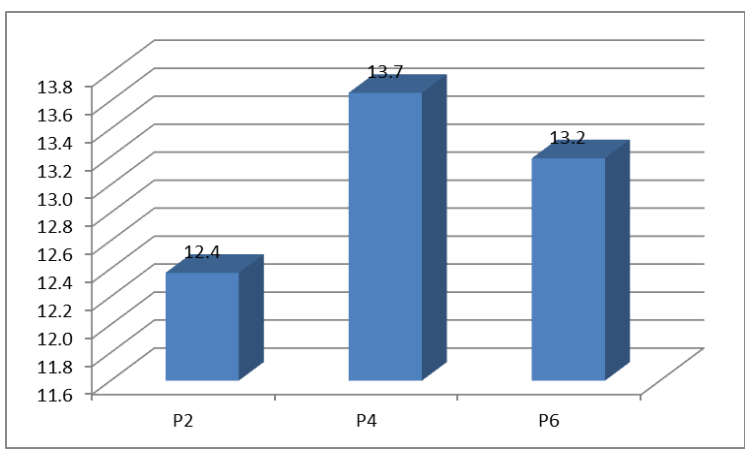

Gambar 1. Refleksi Mahasiswa

\section{Hasil Penelitian dan Pembahasan}

Refleksi dosen, dapat dilakukan dengan cara melihat rekaman pembelajaran yang telah dilakukan(Susoy, 2015, p. 163). Hasil pengamatan memang ditemukan hal-hal yang menunjukkan bahwa mahasiswa kurang memiliki motivasi, namun seorang guru tetap mendorong mereka untuk terus belajar untuk menemukan kebermaknaan belajar, itulah yang disebut sebagai "teaching efficacy"(Ng, Nicholas, \& Williams, 2010, p. 287).
Bahan hasil refleksi dosen dan mahasiswa serta rekaman video dapat digunakan untuk perbaikan pembelajaran. Hal ini saling terkait dalam memahami proses pembelajaran secara utuh. Pola refleksi yang dapat dilakukan oleh dosen seperti pada gambar 2 .

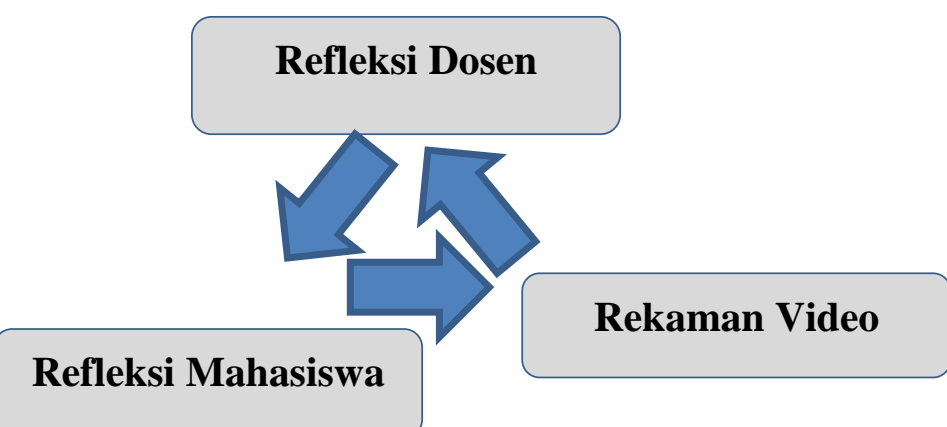

Hasil refleksi dosen diperoleh data bahwa pada pertemuan ke-1 Dosen sudah mempersiapkan kegiatan praktikum dengan baik, yaitu praktikum asam asetat atau asam cuka. Asam cuka dalam kehidupan sehari-hari sangat banyak manfaatnya seperti sebagai cuka makan, misalnya membuat acar. Atau ada juga cuka apel yang berasal dari Malang. Pada praktikum ini mahasiswa pada tahap "pengalaman" mahasiswa masih bingung dalam menggunakan peralatan. Hal ini ditandai dengan seringnya mahasiswa menanyakan tentang kegunaan peralatan. Pertanyaan tersebut sangat wajar, dikarenakan meraka merupakan mahasiswa baru yang sama sekali belum melakukan praktikum. Kegiatan praktikum sebelumnya yang pernah mereka ikuti yaitu ujian akhir Sekolah. Sehingga dengan minimnya pengalaman dan pengetahuan, mereka sering bertanya, di sisi lain bagus. Namun, hal ini berdampak pada waktu praktimum akan semakin lama.

Adanya pengetahuan peralatan dan ketrampilan berdampak pada kognisi mahasiswa, sehingga saat melakukan praktikum mereka sebagian besar tidak memahami prosedur kerja dan hasil pada setiap tahapannya, sehingga hasilnya kurang memuaskan. Pada saat sintesis asam asetat juga menghasilkan rendemen yang sangat kecil, jadi juga menambah kurang bermaknanya proses sistesis asam asetat. Meskipun asam asetan dalam kehidupan sehari-hari sudah sangat dimengerti. 
Hal ini senada dengan hasil refleksi mahasiswa bahwa mereka setelah melakukan refleksi dengan 4 pertanyaan diperoleh skor cukup rendah jika dibandingkan dengan pertemuan 2 dan 3, yaitu 12.4.

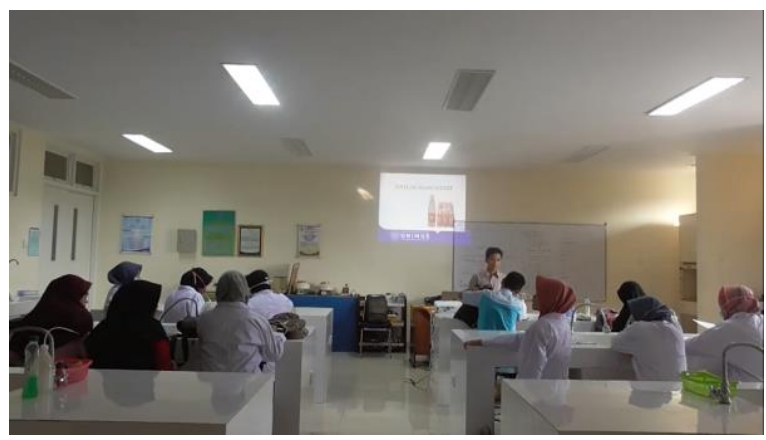

Gambar 3. Pengatar perkuliahan

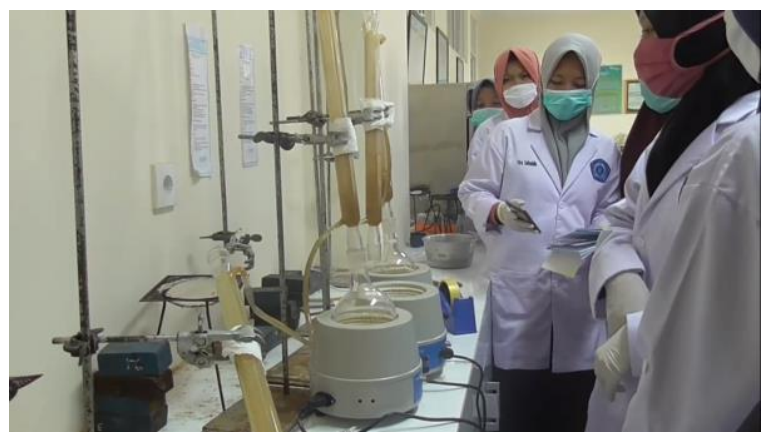

Gambar 4. Proses Destilasi

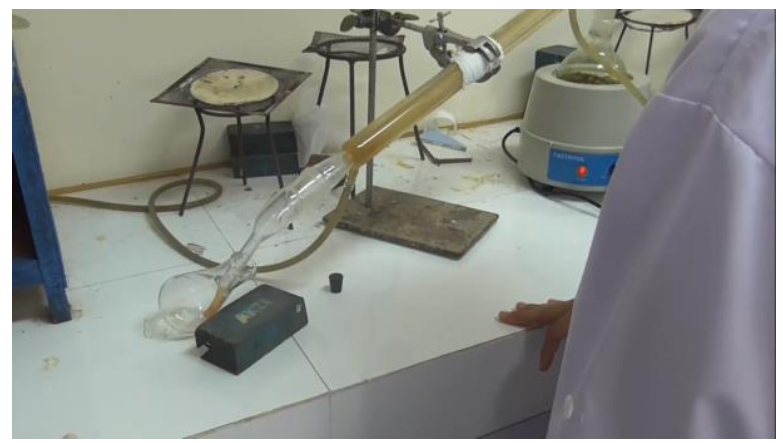

Gambar 4. Hasil Destilasi Minim

Pertemuan selanjutnya praktikum reaski penyabunan (pembuatan sabun dari berbagai minyak). Pada pertemuan ke-2, mahasiswa sudah lebih siap dalam mengerjakan kegiatan praktikum. Hal ini ditunjukkan bahwa mereka sudah menyiapkan bahan-bahan praktikum secara mendiri, selain itu saat pada tahap "konteks", dosen menanyakan apa tujuan praktikum, mereka sudah dapat menjawab dengan tegas dan jelas. Pengalam baru pada praktikum ini salah satunya ketrampilan menyiapkan bahan. Yaitu jumlah $\mathrm{NaOH}$ dan minyak yang dibutuhkan, supaya reaksi penyabunan tidak berlebih, sehingga hasil reaksi tidak terlalu basa, sehingga sabun dapat digunakan. Berikut contoh bilangn pengali jika menggunakan $\mathrm{KOH}$ atau $\mathrm{NaOH}$.

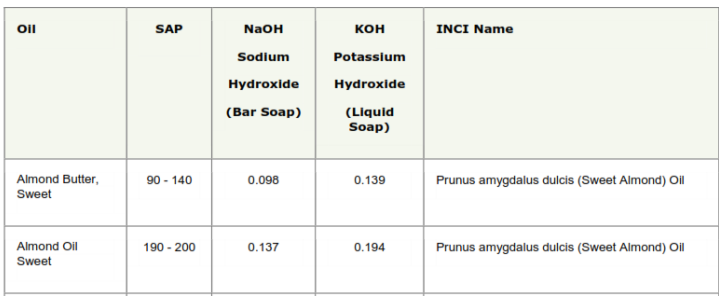

Gambar 5. Bilangan pengali $\mathrm{KOH}$ dan $\mathrm{NaOH}$

Selama proses persiapan dan pelaksanaan praktikum mereka sangat antusis salahs atunya: mereka melakukan improvisasi penggunaan pewarna, bentuk dan bahkan cetakan yang digunakan. Hal ini senada dengan hasil refleksi yang tinggi yaitu 13.7. Hal ini menunjukkan mereka secara jelas mengetahui tujuan, manfaat bahkan aksi setelah meraka melakukan kegiatan praktikum membuat sabun.

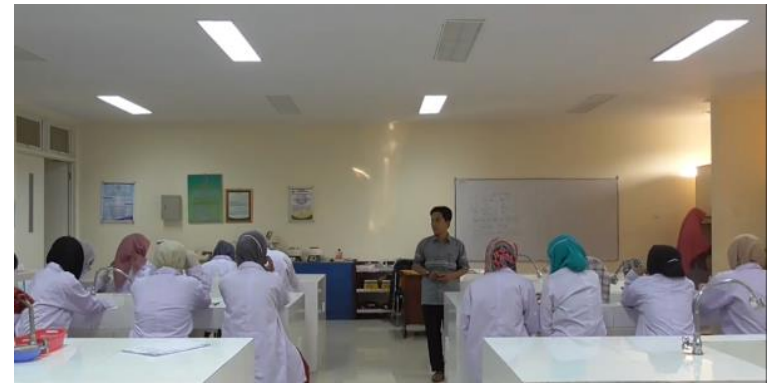

Gambar 6. Tahap Konfirmasi kesiapan

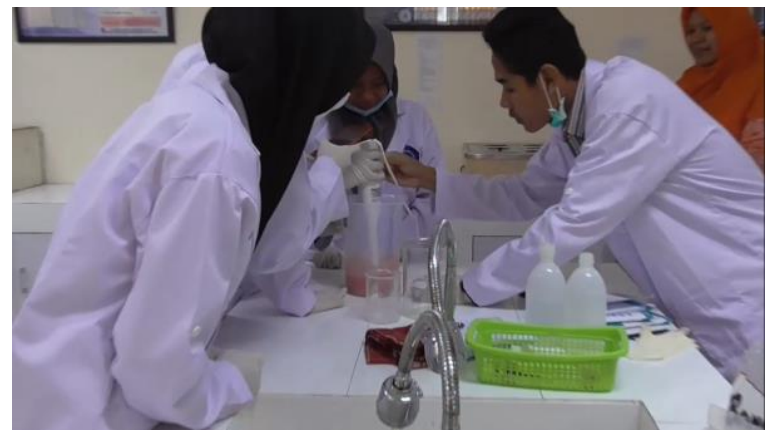

Gambar 7. Reaksi dan pewarnaan Sabun

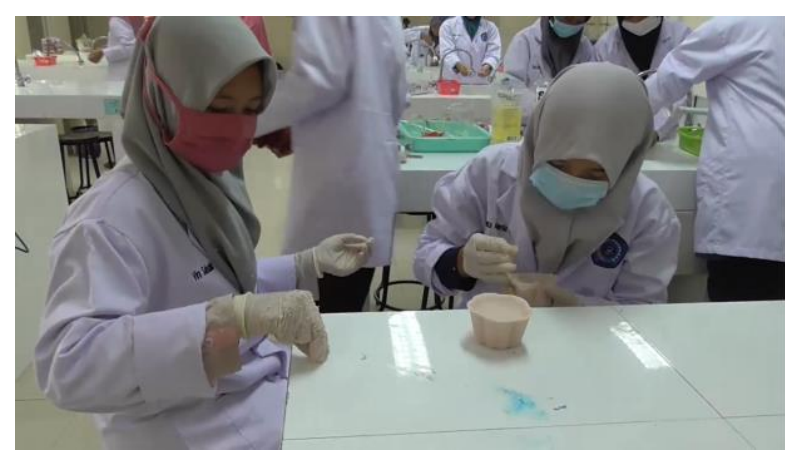

Gambar 8. Pencetakan Sabun 


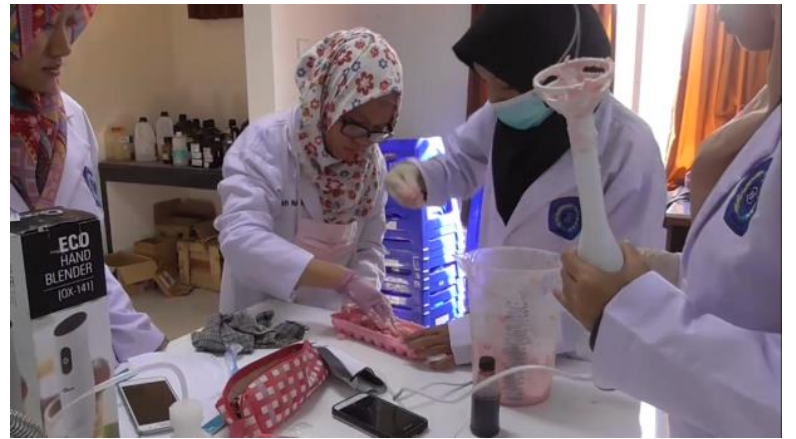

Gambar 9. Pencetakan Sabun

Praktikum terakhir yaitu sintesis butyl asetat. Pada praktikum ini, mahasiswa lebih siap, hal ini dikonfirmasi saat persiapan awal praktikum. Pada praktikum ini, mahasiswa juga menggunakan refluks atau destilasi, berdasarkan pengalaman praktikum pada sintesis asam asetat, mahasiswa jauh cukup berani melakukan refluks, meskipun juga didampingi oleh dosen dan asisten laboratorium. Pada praktikum ini cukup ada beberapa kendala pada ekstraksi. Alat yang dikunakan mengalami kebocoran, sehingga proses ekstraksi ada beberapa produk sintesis tumpah. Secara umum mereka tertaril dengan berbagai jenis alcohol yang digunakan dan aroma hasil sintesis. Butil asetat juga menjadi soal perdebatan diantara mereka, antara aroma apel dan pisang. Aroma tersebut membuat mereka cukup menarik, bahkan produk hasil sitesis digunakan untuk foto.

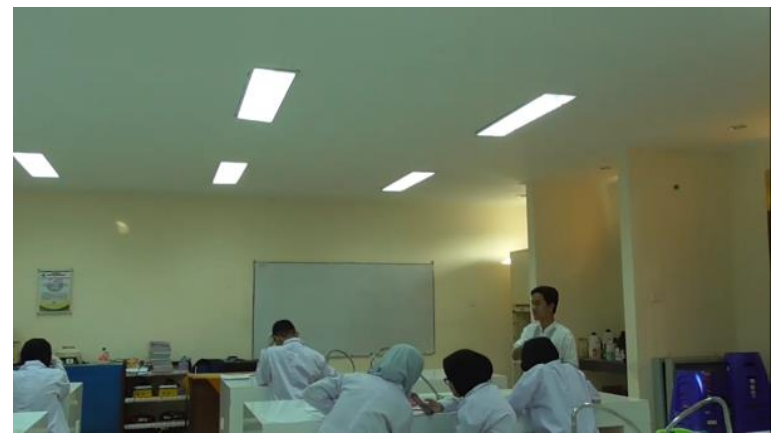

Gambar 10. Konfirmasi kesipan praktikum

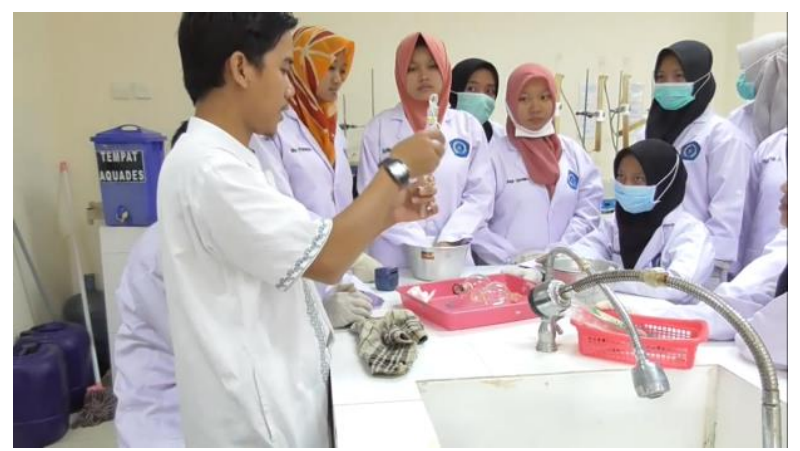

Gambar 11. Penjelasan Ekstrasksi

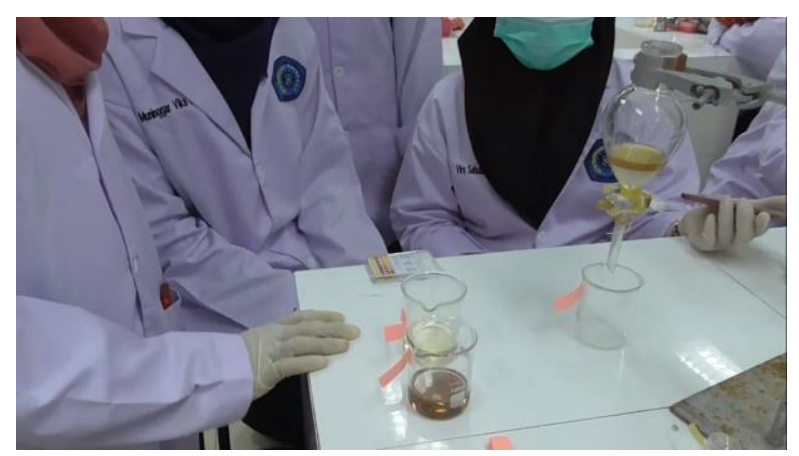

Gambar 12. Ekstraksi Campuran hasil sintesis

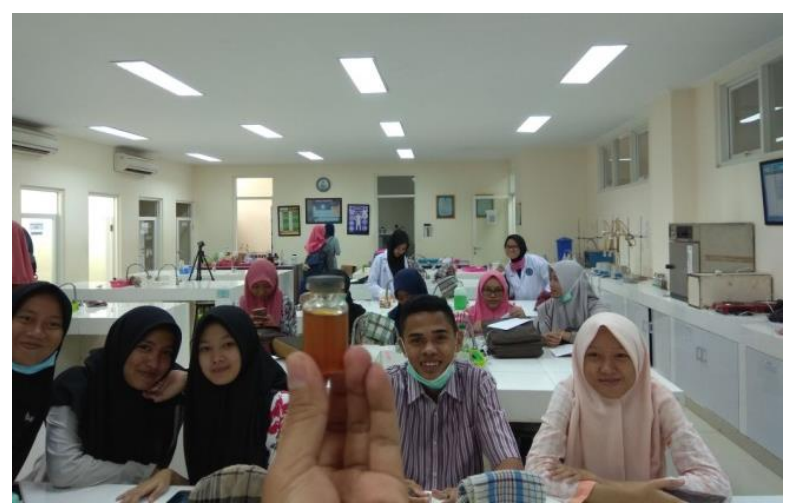

Gambar 13. Berfoto bersama Butyl Asetat

Hasil praktikum membantu mereka mengingat kenangan proses praktikum, sehingga setelah praktikum mereka menemukan kebermaknaan dalam kehidupan sehari-hari. Hal ini sejalan dengan hasil refleksi bahwa pada pertemuan ke3 mahasiswa memperoleh hasil refleksi cukup tinggi yaitu 13.2. Hal ini menunjukkan mereka mampu merefleksikan dengan baik.

Hasil observasi ketiga kegiatan praktikum tersebut dapat digunakan dalam memperbaiki proses praktikum yang dapat menimbulkan kebermanaan belajar bagi mahasiswa calon pendidik kimia.

\section{Simpulan dan Saran}

\section{Simpulan}

Hasilnya berupa 1). Penting disiapkan ketrampilan mahasiswa dalam menggunakan peralatan 2). Topic praktikum semakin dekat dengan produk sehari-hari, akan lebih menarik, 3). Konfirmasi awal sebelum praktikum penting dilakukan untuk memastikan kesipan mahasiswa, 4). Refleksi sangat membantu mengingatkan seberapa jauh pengajar telah dapat mentransfer pengetahuan dan nilai dengan baik. 
Saran

Penelitian yang perlu dilakukan yaitu mengetahui ketrampilan mahasiswa dalam mengidentifikasi peralatan dan ketrampilannya. Selain itu perlu adana perbaikan pembelajaran supaya mahasiswa lebih terampil dan cakap dalam menggunakan peralatan praktikum kimia organik seperti: soxhlet, refluks, ekstraksi, destilasi, penggunaan mantel pemanas, dan hot plate.

\section{Ucapan Terima Kasih}

Tim Peneliti mengucapkan terima kasih kepada Kementrian Riset, Teknologi dan Pendidikan Tinggi yang telah mendanai penelitian kami dalam kurun waktu tahun 2017 2018.

\section{Daftar Pustaka}

Dervent, F. (2015). The effect of reflective thinking on the teaching practices of preservice physical education teachers. Issues in Educational Research, 25(3), 260-275.

Fatemipour, H. (2013). The Efficiency of the Tools Used for Reflective Teaching in ESL Contexts. Procedia - Social and Behavioral Sciences, 93, 1398-1403. https://doi.org/10.1016/j.sbspro.2013.10.0 51

Firdyiwek, Y., \& Scida, E. E. (2014). Reflective course design : An interplay between pedagogy and technology in a language teacher education course. International Journal of EPortfolio, 4(2), 115-131.

Mansfield, C. F., \& Volet, S. E. (2010). Developing beliefs about classroom motivation: Journeys of preservice teachers. Teaching and Teacher Education, 26(7), 1404-1415. https://doi.org/10.1016/j.tate.2010.04.005

Ng, W., Nicholas, H., \& Williams, A. (2010). School experience influences on preservice teachers' evolving beliefs about effective teaching. Teaching and Teacher Education, 26(2), 278-289. https://doi.org/10.1016/j.tate.2009.03.010

Schiefele, U. (2017). Classroom management and mastery-oriented instruction as mediators of the effects of teacher motivation on student motivation.

Teaching and Teacher Education, 64, 115-126.

https://doi.org/10.1016/j.tate.2017.02.004

Susoy, Z. (2015). Watch your teaching : A reflection strategy for EFL pre-service teachers through video recordings, 199, 163-171. https://doi.org/10.1016/j.sbspro.2015.07.5 01

Whitaker, M. C., \& Valtierra, K. M. (2018). Enhancing preservice teachers' motivation to teach diverse learners. Teaching and Teacher Education, 73(April), 171-182. https://doi.org/10.1016/j.tate.2018.04.004

Wijoyo, Y., Rahayu, G. R., \& Dwiprahasto, I. (2016). Evaluation on teaching mentoring program based on reflective pedagogy Paradigm. Indian Journal of Pharmaceutical Education and Research, 50(2), S180-S187. https://doi.org/10.5530/ijper.50.2.34 